\title{
PENGARUH PENAMBAHAN SODIUM TRIPOLIPHOSPHAT TERHADAP TINGKAT KESUKAAN KAMABOKO IKAN MALONG (Muraenesox cinerus)
}

\section{THE EFFECT OF SODIUM TRIPOLIPHOSPHAT ADDITION ON PREFERENCE DAGGER-TOOTH PIKE CONGER FISH (Muraenesox cinerus) KAMABOKO}

\author{
Aulia Azka ${ }^{1}$, Apri Mujiyanti ${ }^{1}$ \\ ${ }_{1}^{1}$ Program Studi Pengolahan Hasil Laut, Politeknik Kelautan dan Perikanan Dumai, Indonesia \\ "Korespondensi: azkaa8586@gmail.com (A Azka) \\ Diterima 15 Maret - Disetujui 1 April 2020
}

\begin{abstract}
ABSTRAK. Ikan malong (Muraenesox cinerus) tersebar dari Sumatera hingga Sulawesi. Ikan ini dapat digunakan sebagai bahan baku kamaboko karena memiliki edible portions yang tinggi dan daging berwarna putih. Setelah dilakukan pencucian kualitas tekstur daging ini relatif kurang baik. Sodium tripoliphosphat (STPP) merupakan salah satu cryprotectant yang dapat meningkatkan tekstur daging. Penelitian ini bertujuan untuk mengetahui pengaruh perbedaan konsentrasi STPP dalam pembuatan kmaboko terhadap tingkat kesukaan panelis. Metode yang digunakan dalam penelitian ini adalah metode eksperimental dengan perlakuan konsentrasi STPP yaitu $0 \% ; 0,4 \% ; 0,6 \% ; 0,8 \%$; dan $1 \%$. Pengamatan yang dilakukan adalah uji kesukaan. Parameter yang diamati meliputi rasa, aroma, warna, tekstur, uji lipat, dan uji gigit. Hasil penelitian menunjukkan bahwa penambahan STPP berpengaruh signifikan terhadap parameter rasa, tekstur, uji lipat, dan uji gigit. Kamaboko dengan penambahan STPP sebesar $0,8 \%$ merupakan kamaboko yang paling disukai panelis.
\end{abstract}

KATA KUNCI: Kamaboko, Muraesenox cinerus, STPP

ABSTRACT. Dagger-tooth pike conger fish (Muraenesox cinerus) spread from Sumatera to Sulawesi. This fish can be used as a kamaboko raw materials because have high edible portions and white meat. After washing process, the textural quality of this fish meat is relatively poor. Sodium tripoliphospat (STPP) was one of cryoprotectant to increase the textural of fish meat. The purpose of this research to determine the effect of different STPP concentration ini making kamaboko against panelist preference level. The method used in this research was experimental with the treatment of differnt STPP concentration: 0\%; 0,4\%; 0,6\%; 0,8\%; and $1 \%$. Observation made are preference. Parameters observed were taste, aroma, color, texture,bite test, and folding test. The result that the addition of STPP has significant effect on increasing the taste, texture, bite test, and folding test. Kamaboko with the addition of STPP concentration 0,8\% is the most preferred panelist.

KEYWORDS: Kamaboko, Muraesenox cinerus, STPP

\section{Pendahuluan}

Kamaboko adalah produk hasil olahan daging ikan yang berbentuk gel dan elastis, produk ini berasal dari Jepang. Di Indonesia produk analog kamaboko seperti bakso ikan dan pempek. Kamaboko terbuat dari daging ikan giling dengan penambahan bahan lainnya seperti pati, garam, gula, dan sodium glutamat. Jenis ikan dan bahan tambahan yang digunakan dalam pembuatan kamaboko merupakan faktor-faktor yang memperngaruhi sifat elastis kamaboko (Mao et al., 2006). Ikan Malong (Muraenesox cinerus) merupakan salah satu ikan yang dapat digunakan sebagai bahan baku pembuatan kamaboko. Ikan malong tersebar di Perairan Indonesia, Malaysia, Filipina, hingga Jepang. Di Indonesia ikan malong tersebar di Sumatera hingga Sulawesi (Satapoomin, 2011). Di Provinsi Riau 
ikan malong banyak ditemukan di Selat Panjang, Kepulauan Meranti. Jumlah produksi ikan malong tahun 2013 mencapai 2,8 ton (BPS Kepulauan Meranti, 2014). Ikan malong merupakan ikan karnivora yang hidup di perairan demersal hingga $100 \mathrm{~m}$ di muara-muara sungai, memiliki bentuk seperti belut. Ikan malong memiliki edible portions sebesar $52,75 \%$ dengan panjang tubuh ikan mencapai $70-80 \mathrm{~cm}$ (Marichamy et al., 2012). Ikan malong dapat digunakan sebagai bahan baku kamaboko karena rendemennya besar dan daging ikan berwarna putih. Rendemen daging ikan malong sebesar $62,89 \%$ dengan komponen dominan air 80,49\% dan protein 12,27\% (Laksono et al., 2019a).

Sodium tripoliphosphat (STPP) adalah salah satu senyawa cryoprotectant yang melindungi produk dari denaturasi protein. Penambahan STPP akan menghasilkan tekstur produk yang baik. Penelitian Etemadian et al. (2012), menyatakan bahwa penggunaan STPP akan berpengaruh terhadap sifat fisik daging. Laksono et al. (2019b), menyatakan bahwa penambahan STPP mampu meningkatkan kualitas tekstur surimi ikan malong. Permukaan surimi dilihat secara mikroskopis yang ditambahkan STPP lebih kompak dibandingkan kontrolnya. Penelitian ini bertujuan untuk mengetahui tingkat kesukaan konsumen dengan penggunaan STPP dalam pembuatan kamaboko ikan malong.

\section{Bahan dan Metode}

Bahan yang digunakan dalam penelitian ini adalah ikan malong, tepung tapioka, tepung maizena, garam, air, gula, merica, dan es curai. Alat yang digunakan yatiu pisau, talenan, baskom, timbangan digital, kompor, cetakan silinder stainless steel, meat grinder, food processor, kain belacu, panci, plastik seal.

Metode penelitian ini yaitu metode eksperimental menggunakan 5 perlakuan dengan 15 orang panelis sebagai ulangan, untuk mengtahui tingkat penerimaan panelis terhadap kamaboko. Lima perlakuan dari penambahan konsentrasi STPP yaitu: 0\% (KM1); 0,4\% (KM2); 0,6\% (KM3); 0,8\% (KM4); dan 1\% (KM5). Parameter yang diamati yaitu rasa, aroma, warna, tekstur, uji lipat, dan uji gigit. Analisis data dari hasil penelitian berupa nilai hedonik produk menggunakan uji Kruskall-Wallis yang dilanjutkan dengan uji lanjut Duncan untuk melihat pengaruh konsentrasi STPP yang digunakan terhadap parameter rasa, aroma, warna, tekstur, uji lipat, dan uji gigit. Analisis data menggunakan software SPSS versi 26.0 .

\section{Hasil dan Pembahasan}

\subsection{Rasa}

Rasa merupakan salah satu faktor yang sangat menentukan produk dapat diterima atau ditolak konsumen. Nilai rata-rata parameter rasa berkisar dari $5,23-7,53$, yang berarti panelis menilai rasa kamaboko ikan malong dari netral hingga suka. Nilai rata-rata rasa tertinggi pada kamaboko ikan malong dengan konsentrasi STPP 0,8\%. Hasil uji rasa dapat dilihat pada Gambar 1.

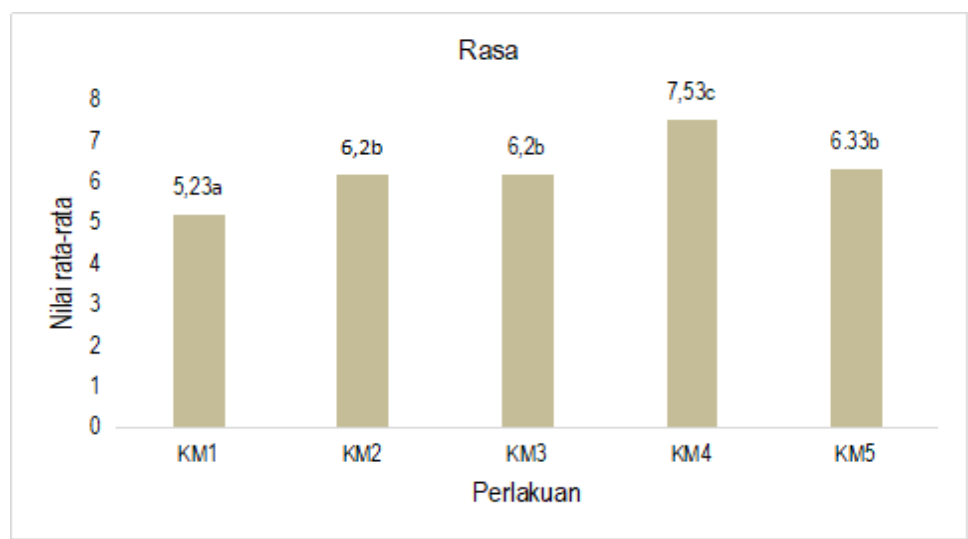

Gambar 1. Hitogram Nilai Rasa Kamboko Ikan Malong dengan Berbagai Konsentrasi STPP 
Hasil analisis Kruskal-Wallis menunjukkan bahwa penggunaan STPP dengan berbagai konsentrasi memberikan pengaruh yang berbeda terhadap parameter rasa. Hal ini diperkuat dengan hasil uji lanjut yang menunjukkan adanya perbedaan nilai rasa antar masing-masing perlakuan. Penelitian Sitompul et al., (2017) menunjukkan bahwa kamaboko dengan berbeda konsentrasi karagenan menghasilkan perbedaan nyata dengan nilai rata-rata sebesar 7,27 - 8,17. Rasa pada makanan dipengaruhi oleh protein, karbohidrat, dan lemak yang dalam makanan tersebut (Suryaningrum et al., 2000). Asam amino pembentuk rasa pada ikan antara lain glutamate, glisin, alanin, arginin, metionin, valin, dan prolin. Asam amino tersebut berpengaruh terhadap parameter rasa pada sampel (Pratama et al., 2017). Rasa kamaboko ikan malong juga dipengaruhi oleh bumbu tambahan saat proses pengolahan.

\subsection{Aroma}

Aroma suatu produk sangat berpengaruh terhadap selera konsumen, aroma berkaitan dengan indra penciuman yang menimbulkan keinginan atau hasrat untuk mengkonsumsinya. Nilai rata-rata parameter rasa berkisar dari 6,33 - 6,73, yang berarti panelis menilai aroma kamaboko ikan malong agak suka. Aroma suatu produk ditentukan dari perpaduan bahan-bahan pembentuk seperti tepung dan bumbu-bumbu. Hasil uji aroma dapat dilihat pada Gambar 2.

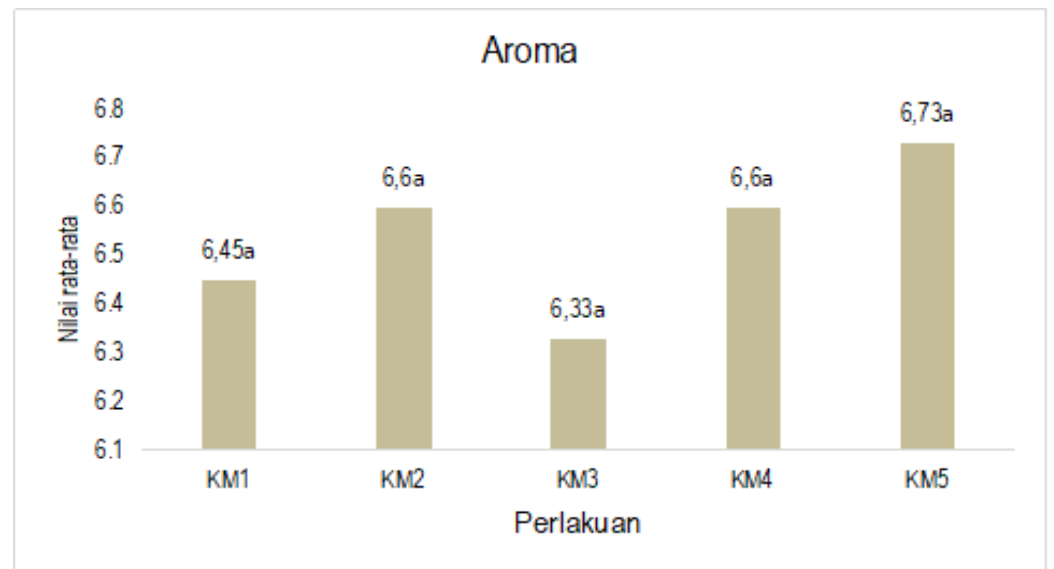

\section{Gambar 2. Hitogram Nilai Aroma Kamboko Ikan Malong Dengan Berbagai Konsentrasi STPP}

Hasil analisis Kruskal-Wallis menunjukkan bahwa penggunaan STPP dengan berbagai konsentrasi tidak memberikan pengaruh yang signifikan terhadap parameter aroma. Hal ini dikarenakan aroma ikan telah direduksi saat pencucian daging untuk menjadi surimi. Surimi yang baik yakni surimi yang tidak berbau dan berwarna. Penelitian Sahlan et al. (2018), menunjukkan hasil yang sama bahwa kamaboko dengan jenis ikan berbeda tidak memberikan pengaruh yang signifikan terhadap penilian panelis untuk parameter aroma.

\subsection{Warna}

Warna pada makanan merupakan parameter yang penting karena akan meningkatkan daya tarik dan memberi informasi yang lebih kepada konsumen. Warna juga dapat menentukan kualitas suatu makanan. Makanan yang memilik rasa dan penampakan baik, namun warnanya memberikan kesan yang menyimpang dari warna seharusnya, maka makanan tersebut sebaiknya tidak dikonsumsi Nilai rata-rata parameter warna berkisar dari 6,07 - 6,73, yang berarti panelis menilai warna kamaboko ikan malong agak suka. Nilai parameter warna tertinggi pada kamaboko ikan malong dengan konsentrasi STPP $0,8 \%$. Warna kamaboko yang dihasilkan yakni putih krem. Warna kamaboko dapat dipengaruhi oleh proses pemasakan. Hasil penelitian Bachtiar et al. (2014), menunjukkan bahwa nilai derajat putih kamaboko ikan lele cenderung menurun dengan suhu setting meningkat. analisis Kruskal-Wallis menunjukkan bahwa penggunaan STPP dengan berbagai konsentrasi tidak memberikan pengaruh yang signifikan terhadap parameter warna. Hasil uji warna dapat dilihat pada Gambar 3. 


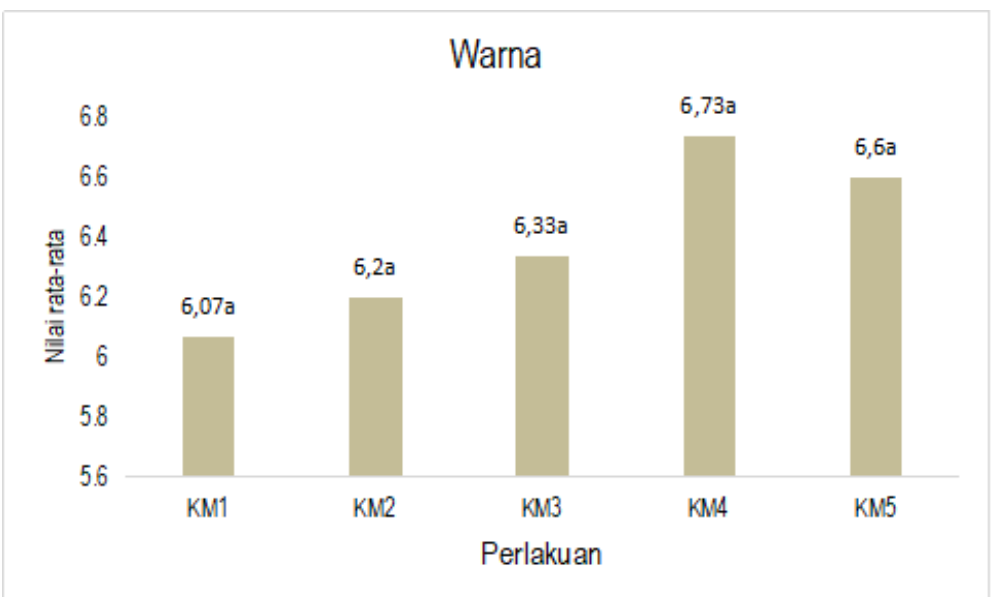

\section{Gambar 3. Hitogram Nilai Warna Kamboko Ikan Malong Dengan Berbagai Konsentrasi STPP}

\subsection{Tekstur}

Tekstur merupakan karakteristik yang sangat penting untuk produk fish jelly karena sifat elastisitas dan kekeyalannya. Penilaian tekstur produk berasal dari sentuhan permukaan kulit, biasanya biasanya menggunakan ujung jari tangan sehingga dapat dirasakan tekstur suatu bahan. Hasil uji hedonik terhadap tekstur kamaboko ikan malong dengan penambahan STPP $1 \%$ memiliki nilai tertinggi yaitu 7,4 , sedangkan kamaboko ikan malong kontrol memiliki nilai terendah yaitu 4,87 . Hasil uji tekstur dapat dilihat pada Gambar 4.

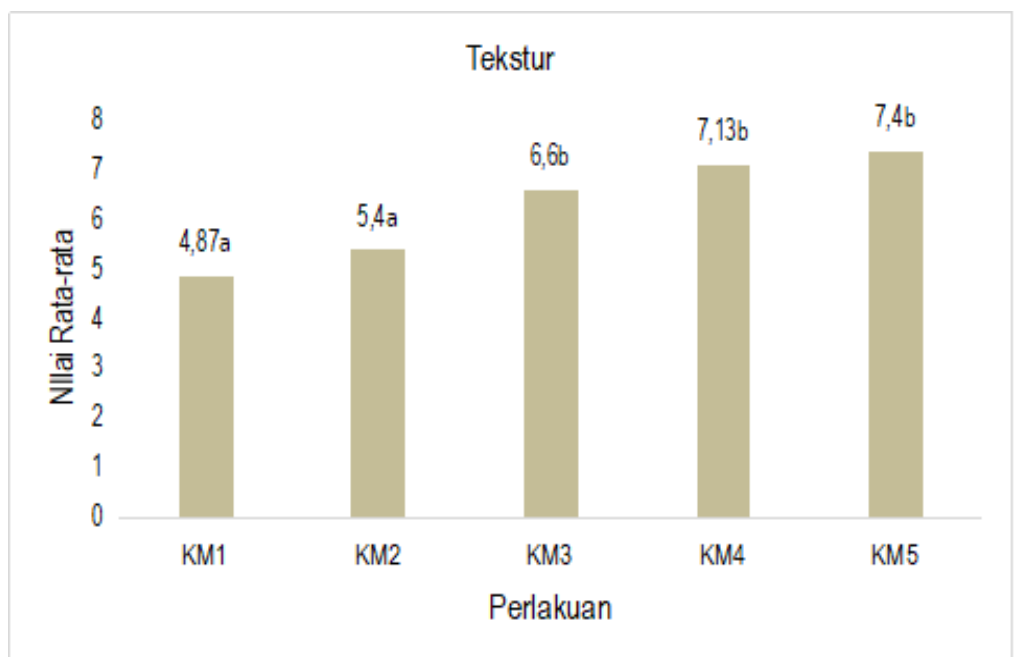

\section{Gambar 4. Hitogram Nilai Tekstur Kamboko Ikan Malong Dengan Berbagai Konsentrasi STPP}

Hasil analisis Kruskal-Wallis menunjukkan bahwa penggunaan STPP dengan berbagai konsentrasi memberikan pengaruh yang signifikan terhadap parameter tekstur. Hal ini diperkuat dengan hasil uji lanjut yang menunjukkan adanya perbedaan nilai tekstur antar masing-masing perlakuan. Kamaboko ikan malong dengan penambahan konsentrasi STPP sebesar $1 \%$ memiliki tekstur yang paling disukai. Hasil penelitian Laksono et al. (2019b), menunjukkan bahwa penambahan STPP mampu meningkatkan kualitas gel surimi ikan malong dilihat dari hardness, adhesiveness, fracturability, gumminess dan chewiness yang meningkat. STPP dapat berinteraksi dengan sisi positif molekul protein dan meningkatkan jumlah sisi negatif total, sehingga ikatan intramolekul protein meningkat dan akhirnya mampu menahan air lebih baik (Etemadian et al., 2012). Ikan malong yang berdaging putih juga berpengaruh terhadap tekstur kamaboko yang dihasilkan. Suprianto et al. (2015), menyatakan bahwa ikan berdaging putih mengandung protein aktin miosin yang cukup tinggi sehingga membuat daging lebih kompak, padat, dan mudah dibentuk. 


\subsection{Uji Lipat}

Uji lipat merupakan salah satu cara menentukan kekuatan gel dengan penilaian sensor. Uji lipat dijadikan standar mutu surimi secara internasional. BSN (2009), menyatakan bahwa level mutu terdiri dari AA (Skor 5), A (skor 4), B (skor 3), C (skor 2) dan D (Skor 1). Nilai rata-rata uji lipat kamaboko ikan malong dengan konsentrasi STPP berbeda berkisar antara 3,35 - 4, yang artinya panelis menilai kamaboko ikan malong dari cukup kenyal hingga kenyal. Nilai rata-rata tertinggi pada sampel KM\$ yaitu penambahan STPP sebesar 4gr. Hasil uji lipat dapat dilihat pada Gambar $\mathbf{5}$.

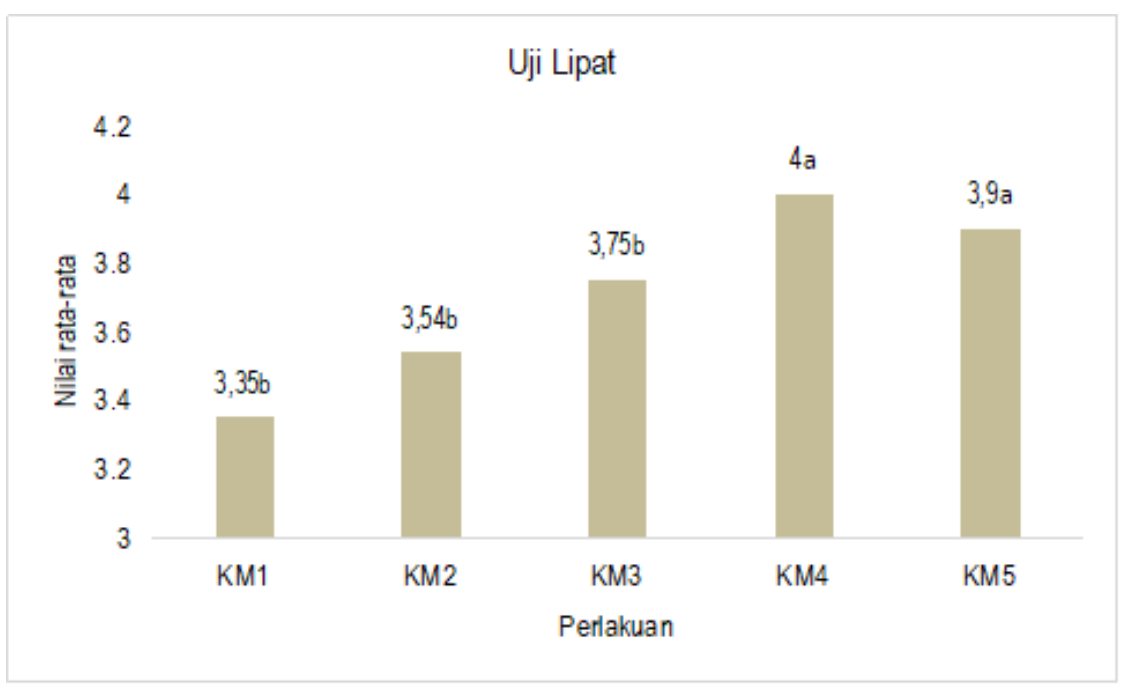

\section{Gambar 5. Hitogram Nilai Uji Lipat Kamboko Ikan Malong Dengan Berbagai Konsentrasi STPP}

Hasil analisis Kruskal-Wallis menunjukkan bahwa penggunaan STPP dengan berbagai konsentrasi memberikan pengaruh yang signifikan terhadap penilaian uji lipat. Hal ini diperkuat dengan hasil uji lanjut yang menunjukkan adanya perbedaan nilai uji lipat antar masing-masing perlakuan. Kamaboko yang tidak ditambah STPP (KM1) memberikan nilai uji lipat yang berbeda dengan kamaboko dengan penambahan STPP $0,8 \%$ dan $1 \%$. Akan tetapi tidak memberikan pengaruh yang berbeda nyata dengan kamaboko dengan penambahan STPP $0,4 \%$ dan $0,6 \%$. Kemampuan protein untuk menahan air dan menyerap kembali air ketika dilakukan thawning dapat meningkat jika ada penambahan fosfat pada surimi ikan (Nopianti et al., 2010). Hasil penelitian Laksono et al.(2019b), menunjukkan bahwa penambahan STPP $0,2 \%$ dan $0,5 \%$ menghasilkan nilai uji lipat terbaik pada kamaboko ikan malong, namun penambahan STPP hingga 0.8\% masih memberikan efek terhadap uji lipat yang baik.

\subsection{Uji Gigit}

Uji gigit dilakukan untuk memberikan taksiran secara subjektif yang dilakukan panelis terhadap kekeyalan suatu produk. Uji gigit dilakukan dengan cara menggigit sampel antara gigi seri atas dan bawah. Nilai rata-rata uji gigit kamaboko ikan malong antara 6,23 - 7,27. Nilai uji gigit yang dihasilkan termasuk ke dalam kriteria daya lenting diterima hingga daya lenting agak kuat. Produk kamaboko penelitian ini tergolong dapat diterima oleh konsumen. Menurut Balai Pembinaan dan Pengawasan Mutu Hasil Perikanan (2001), produk komersial yang masih dapat diterima mempunyai uji gigit sebesar 5 -6. Hasil penilaian uji gigit dapat dilihat pada Gambar 6. 


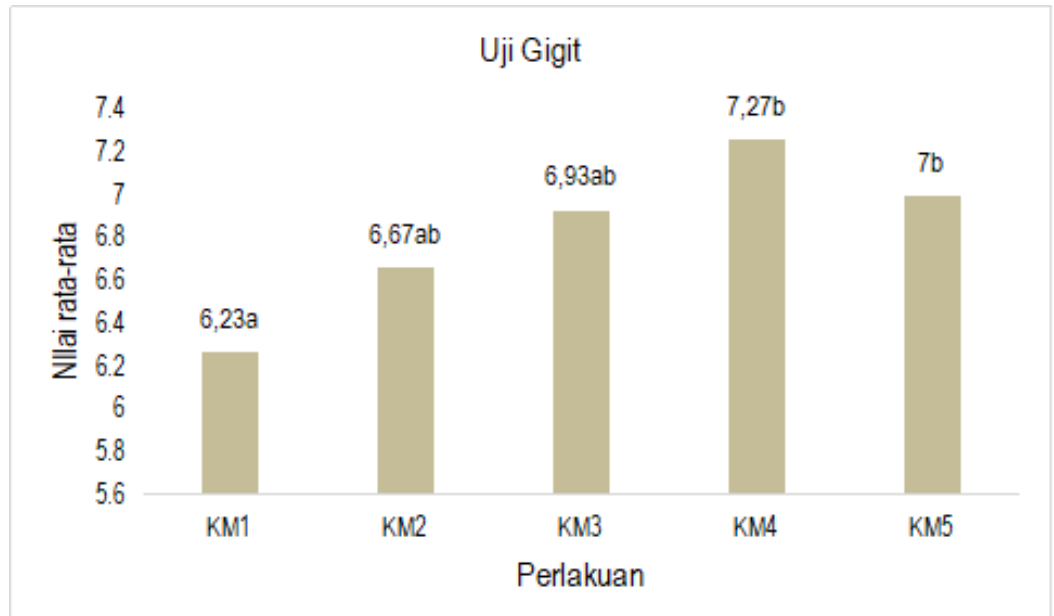

\section{Gambar 6. Hitogram Nilai Uji Gigit Kamboko Ikan Malong Dengan Berbagai Konsentrasi STPP}

Hasil analisis Kruskal-Wallis menunjukkan bahwa penggunaan STPP dengan berbagai konsentrasi memberikan pengaruh yang signifikan terhadap penilaian uji gigit. Hal ini diperkuat dengan hasil uji lanjut yang menunjukkan adanya perbedaan nilai gigit lipat antar masing-masing perlakuan. Kamaboko yang tidak ditambah STPP (KM1) memberikan nilai uji gigit yang berbeda dengan kamaboko dengan penambahan STPP $0,8 \%$ dan $1 \%$. Akan tetapi tidak memberikan pengaruh yang berbeda nyata dengan kamaboko dengan penambahan STPP 0,4\% dan 0,6\%. Sitompul et al. (2017), meyatakan bahwa proses pencucian berpengaruh terhadap tinggi rendahnya nilai uji gigit yang dihasilkan oleh semua kamaboko. Proses pencucian dapat meningkatkan karakteristik gel karena trpomiosin, troponin dan miosin rantai ringan pada pencucian satu dan dua akan hilang, hal tersebut bercampur dengan interaksi-interaksi protein yang mendorong pembentukan gel (Ismail et al., 2010).

\section{Kesimpulan}

Kamaboko ikan malong dengan penambahan konsentrasi STPP berbeda memberikan pengaruh yang signifikan terhadap penilaian panelis dengan parameter rasa, tekstur, uji lipat dan uji gigit. Parameter aroma dan rasa penambahan STPP tidak memberikan pengaruh yang signifikan. Konsentrasi STPP terbaik yaitu kamaboko ikan malong dengan konsentrasi STPP 0,8\%. Hal ini dilhat dari parameter rasa, warna, uji lipat, dan uji gigit panelis memberikan penilaian yang tertinggi.

\section{Daftar Pustaka}

Bachtiar, I., Agustini, T, W., \& Anggo, A, P. (2014). Efektivitas Pencucian dan Suhu Setting $(20,40,50$ oC) pada Gel Kamaboko Ikan Lele Dumbo (Clarias gariepenus). Jurnal Pengolahan dan Bioteknologi Hasil Perikanan. 3(4): 45-50.

Balai Pembinaan dan Pengawasan Mutu Hasil Perikanan. (2001). Petunjuk Mince Fish dan Surimi Non Ekonomis. Direktorat Jendral Perikanan. Jakarta. 20hlm.

[BPS] Badan Pusat Statistik Kepulauan Meranti. (2014). Produksi Perikanan Laut menurut Jenis tahun 2013. https://merantikab.bps.go.id/

[BSN] Badan Standarisasi Nasional. (2009). Cara uji fisika Bagian 6: Penentuan mutu pasta pada produk perikanan. SNI 2372.6: 2009. Jakarta (ID): Badan Standarisasi Nasional.

Etemadian,Y., Shabanpour, B., Mahoonak, A, S., \& Shabani, A. (2012). Combination effect of phosphate and vacuum packaging on quality parameters of Rutilus frisii kutum fillets in ice. Journal Food Research International. 45(1): 9-16.

Ismail, I., Huda, N., Arifin, F., \& Ismail, N. (2010). Effects of Washing on the Functional Properties of Duck Meat. Int, J. Puol. Sci. 9 (6):556-561. 
Laksono, U, T., Nurhayati, T., Suptijah, P., Nur'aenah, N., \& Nugroho, T, S. (2019a). Karakteristik Ikan Malong (Muraenesox cinerus) sebagai Bahan Baku Pengembangan Produk Diversifikasi. JPHPI. 22(1): 60-70.

Laksono, U. T., Suprihatin., Nurhayati, T., \& Romli, M. (2019). Peningkatan Kualitas Tekstur Surimi Ikan Malong dengan Sodium Tripolifosfat dan Aktivator Transglutaminase. JPHPI. 22(2): 198-208.

Mao, W., Mika, F., Noboru, F. (2006). Gel Strength of Kamaboko Gels Produced by Microwave Heating. Food Science and Technology Research. 12(4):241-246.

Marichamy, G., Badhul, H, M, A., Vignesh, R., Shalini, R., \& Nazar, A.R. (2012). Report on The Distribution of Essential and Non Essential Fatty Acids in Common Edible Fishes of Porto-Novo Coastal Waters, Southeast Coast of India. Asian Pacific Journal of Tropical Biomedicine. S1102S1115.

Nopianti, R., Huda, N., \& Ismail, N. (2010). A review: Loss of Functional Properties of Proteins During Frozen Storage and Improvement of Gel-Forming Properties of Surimi. American Journal of Food Technology. 6(1): 19-30.

Pratama, R.I., Rostini, I., \& Rochima, E. (2017). Amino Acid Profile and Volatile Components of Fresh and Steamed Vaname Shrimp (Litopenaeus vannamei). Prosiding 1st International Conference on Food Security Innovation (ICFSI), Le Dian Hotel, October 18 - 20. Serang: 57-68.

Sahlan, S., Liviawaty, E., Rostini, I., \& Pratama, R, I. (2018). Perbedaan Jenis Ikan Sebagai Bahan Baku Terhadap Tingkat Kesukaan Kamaboko. Jurnal Perikanan dan Kelautan.IX(1): 129-133

Satapoomin, U. (2011). The Fishes of Southwestern Thailand, the Andaman Sea, A Review of Research and A Provisional Checklist of Species. Phuket Marine Biological Center Research Bulletin. 70: 29-77.

Sitompul, R., Darmanto, Y, S., \& Romadhon. (2017). Aplikasi Karagenan terhadap Kekuatan Gel pada Produk Kamaboko dari lkan yang Berbeda. J.Peng.\& Biotek. Hasil Pi. 6(1): 38-45.

Suprianto, Ilza, M., \& Syahrul. (2015). Studi Penerimaan Konsumen Terhadap Bakso Ikan Malong (Muarenesox talabon) dengan Bahan Pengikat Berbeda. JOM. 2(2): 1-12.

Suryaningrum., D., Murdinah., \& Arifin M. (2000). Penggunaan Kappa-Karaginan sebagai Penstabil pada Pembuatan Fish Meat Loaf dari Ikan Tongkol (Euthyinnus pelamys. L). Jurnal Penelitian Perikanan Indonesia. 8(6). 
